The Agriculturists 18(1):129-136(2020) ISSN 2304-7321 (Online), ISSN 1729-5211 (Print)

A Scientific Journal of Krishi Foundation

Indexed Journal

DOI: https://doi.org/10.3329/agric.v18i1.49465

\title{
Millet-Jute-T. Aman Cropping Pattern for Increasing System Productivity in the Active Brahmaputra-Jamuna Floodplain Chars
}

\author{
A. A. Mahmud ${ }^{1}$, M. Jahangir Alam ${ }^{1}$, M. A. Islam ${ }^{2}$, M. S. H. Molla ${ }^{3}$ and M. A. Ali ${ }^{4}$ \\ ${ }^{I}$ On-Farm Research Division, Bangladesh Agricultural Research Institute (BARI) Gaibandha, \\ Bangladesh $;{ }^{2}$ On-Farm Research Division, BARI, Bogura, Bangladesh $;{ }^{3}$ On-Farm Research Division, \\ BARI, Rangpur, Bangladesh; ${ }^{4}$ On-Farm Research Division, BARI, Gazipur, Bangladesh
}

*Corresponding author and Email: jahangir.bari@gmail.com

Received: 22 April 2020

Accepted: 25 June 2020

\begin{abstract}
Increasing system productivity in a planned way is an important base for attaining food security, where bringing marginal land like Charland under intensive crop cultivation is highly desirable. The field trial was conducted in the Charland of the Jamuna River under Saghata upazilla of Gaibandha during 201718 \& 2018-19 to increase the productivity and profitability through the development of three cropsbased improved cropping patterns instead of the local practice (double-crop). Three crops based improved cropping pattern namely Millet (BARI Kaon-2)-Jute (O-9897)-T. Aman (Gainja) was compared with the existing cropping pattern of Millet (Local)-Fallow-T. Aman (Gainja). The experiment was laid out in six dispersed replications maintaining RCB design. The introduced improved cropping pattern produced the higher system productivity based on rice equivalent yield, REY $\left(12.95 \mathrm{t} \mathrm{ha}^{-1}\right)$, than the existing cropping pattern $\left(4.20 \mathrm{t} \mathrm{ha}^{-1}\right)$, which is three times higher than the existing pattern. Total field duration and turnaround time were 323 and 42 days, respectively in improved pattern and 215 and 150 days, respectively in the existing pattern, which revealed that 108 days more could be made productive through the introduction of improved cropping pattern. The alternate pattern increased production efficiency and land-use efficiency by $35 \%$ and $30 \%$, respectively than that of the existing cropping system. The gross margin was also three times higher in the improved cropping pattern $\left(1,41,600 \mathrm{Tk} \mathrm{ha}^{-1} \mathrm{yr}^{-1}\right)$ compared to the farmers' existing cropping pattern $\left(38,350 \mathrm{Tk} \mathrm{ha}^{-1} \mathrm{yr}^{-1}\right)$. The marginal benefit-cost ratio (MBCR) was calculated 2.44 in an improved cropping pattern over the existing cropping pattern. The inclusion of an extra one crop (Jute) in the existing cropping pattern and replacement of the local millet variety by high yielding variety (BARI Kaon-2) could play a significant role to increase the system productivity as well as profitability in the Charland of Saghata, Gaibandha.
\end{abstract}

Keywords: Cropping intensity, char areas, rice equivalent yield, production efficiency, and land-use efficiency

\section{Introduction}

The agricultural opportunities in the Charland vary due to coarse-textured soil, low water holding capacity, and low fertility, and these are the major constrains for achieving satisfactory yield. Natural dynamics of erosion and accretion process of the rivers, the sand bars emerging as islands within the river channel (island chars) or as attached land to the river banks (attached chars) and once vegetated such lands are commonly called "Charland" in Bengali term, 
its English meaning is "Riverine Island". In general, very poor diversity of crops exists in char areas where T. Aman is the predominant crop in Kharif II season (June to October). There is about one million ha of char lands in Bangladesh (Karim et al., 2014; Sattar and Islam, 2010). In another, char land areas are estimated to be 0.72 million hectares in Bangladesh which is about $5 \%$ of the country area and about 6.5 million people (5\% of the country's population) live there (EGIS, 2000). In Gaibandha, the char lands developed by the Brahmaputra and the Teesta rivers are about 27,000 ha, mostly extended in Fulchari, Saghata, and Sundarganj upazilla (Karim et al., 2017) and these Charland are changing every year depending on river erosion and as well as siltation.

Charlands may be permanent one i.e. never flooded, and another type is unstable char which is affected by seasonal flood every year. During the flood, lots of silt are deposited in the river and make the unstable char. Farmers generally sow crops seeds when the flooded water recedes and gradually the char lands raised. In char areas, farmers are mostly poor and marginal farmers have the land of 0.02 to 0.2 ha. The major constraints for economic crop production in the char areas are slow technology transfer, lack of quality seeds and fertilizers, inadequate irrigation facility, lack of quality pesticides, lack of storage facility, poor marketing facility, lack of credit facility among the farmers etc. (Karim et al., 2017).

Millet is a minor cereal widely grown in char areas of Gaibandha and contribute a significant role in the economy. In Gaibandha, the area under millet cultivation is 155 hectare $(13 \%$ of total area in Bangladesh) and production is 203 metric ton with an average yield of $1.3 \mathrm{t} \mathrm{ha}^{-1}$ (BBS, 2015). Millet can grow well in char areas with low input (fertilizer and irrigation) and it is popular among the char dwellers' due to its low production cost with high market price. Besides, millet is becoming popular among the diabatic patient for its high fibre content and calories.
Each $100 \mathrm{~g}$ millet grain contains 351 calories, $11.2 \mathrm{~g}$ protein, $4 \mathrm{~g}$ fat, $63.2 \mathrm{~g}$ carbohydrate, and $6.7 \mathrm{~g}$ fiber, $2.8 \mathrm{mg}$ iron, $3.2 \mathrm{mg}$ niacin, $0.1 \mathrm{mg}$ riboflavin, and $31 \mathrm{mg}$ calcium (Islam et al., 2017). In addition to the calorific value, millet has also some medicinal values. Millet acts as a diuretic. It is useful in preventing arthritis, indecent, and indigestion (Islam et al., 2017). Men and women are used to treating infertility. Millet grain is used as hodgepodge, moa, navel, and cake that is a part of the diet among the char dwellers. Now a day, its flour is also using in the bakery industry.

Jute is a long natural fiber popularly known as the "golden fibre" in Bangladesh. The jute fibre is also locally known as pat, kosta, nalita, bimli, etc. It is one of the cheapest and the strongest among all the natural fibers and considered as fibre of the future. Bangladesh is the secondlargest jute producing country in the world after India. Currently, about 8.9 million bales of jute fibre are being produced from the area of 0.8 Mha (million hectares) of land (BBS, 2018). Nonetheless, Bangladesh remains the world's largest exporter of jute fiber, accounting for as much as $70 \%$ of global jute exports (Rahman et al., 2017). The jute fiber produced in Bangladesh is often considered the best quality in the world. Jute is not only a major textile fibre but also a raw material for non-traditional and value-added non-textile products. Recently, jute fibers are used in a wide range of diversified products: decorative fabrics, chicsaris, salwar kamizes, soft luggages, footwear, greeting cards, molded door panels, and other innumerable useful consumer products.

In the char area of Gaibandha, farmers usually cultivate local T. Aman variety mostly in rainfed conditions call Gainja, with very low yield (about 2-2.5 $\mathrm{t} \mathrm{ha}^{-1}$ ). It is commonly cultivated in all the Charlands due to its low requirement of inputs (seed, fertilizer, and irrigation). Moreover, in the Charlands of Saghata in Gaibandha, the predominant cropping pattern is Millet -Fallow-T. Aman rice with local varieties, that is very low yield and 
less profitable. There has an ample opportunity to increase system productivity through intensification by the inclusion of jute in between the existing cropping pattern and also use the high yielding varieties of millet (BARI Kaon-2) and jute (O-9897), which could play a vital role to increase system productivity. Keeping this view in mind, the study was undertaken to increase the system productivity and profitability by introducing an additional crop (jute) and BARI Kaon-2 instead of local Kaon in the existing cropping pattern, and secondly, to popularize this pattern to the farmers of Saghata, Gaibandha.

\section{Materials and Methods}

The experiment was conducted during 2017-18 \& 2018-19 at farmers' field of Chinirpotol char in Saghata, Gaibandha $\left(25^{\circ} 6^{\prime} \mathrm{N}, 8^{\circ} 35^{\prime} \mathrm{E}\right.$ and 18 $\mathrm{m}$ above sea level) under the AEZ-7 (Active Brahmaputra-Jamuna Floodplain) with the active support of On-Farm Research Division (OFRD), Bangladesh Agricultural Research Institute, Gaibandha. The climate of the experimental site is subtropical monsoon with high rainfall from May to September. The annual average rainfall is $2086 \mathrm{~mm}$, of which 93\% occurs from May to October. Monthly average temperature ranges $18.2^{\circ} \mathrm{C}$ in January to $28.6^{\circ} \mathrm{C}$ in August, with maximum and minimum values of $34.4^{\circ} \mathrm{C}$ and $11.6^{\circ} \mathrm{C}$ in April and January, respectively (Fig. 1 ). The soil of the experimental site was sandy and silty alluvium, rich with weatherable minerals with slightly alkaline in reaction (FRG, 2018). Initial soil was collected from the plot before starting the experiment and analyzed accordingly. The soil status showed that organic matter was very low, nitrogen was limiting whereas, K, S, Zn, and B status were very low to medium (Table 1).

The experiment was laid out in a randomized complete block design (RCBD) with 6 dispersed replications on farmers' field. Two cropping patterns viz., improved pattern Millet (var. BARI Kaon-2)-Jute (var. O-9897)-T. Aman (var.
Gainja) and farmers' existing pattern Millet (var. Local)-Fallow- T. Aman (var. Gainja) were tested to evaluate agronomic performance and economic return. The unit plot size was $100 \mathrm{~m}^{-2}$. (10m x 10m). Seeds were sown@ $10 \mathrm{~kg} \mathrm{ha}^{-1}$ in millet and $1.5 \mathrm{~kg} \mathrm{ha}^{-1}$ in jute on 1-30 January and 25 April-5 May in each of the year. Twenty-fiveday-old rice seedlings were uprooted carefully from the seedbed and transplanted from 20 September to 10 October, with 2-3 seedlings hill ${ }^{-}$ ${ }^{1}$ each of the years in the alternative pattern, and 25 August to 15 September in the existing pattern. Fertilizer was applied in all crops on soil test based (STB) according to the fertilizer recommendation guide (FRG, 2012) presented in Table 2. In millet and jute, half of $\mathrm{N}$ and all of $\mathrm{P}$, $\mathrm{K}, \mathrm{S}, \mathrm{Zn}$, and $\mathrm{B}$ were applied during final land preparation. The remaining $\mathrm{N}$ was applied at 3540 days after sowing (DAS) in millet and 40-45 DAS in jute. In Aman rice, all P, K, S, and $\mathrm{Zn}$ were broadcast on the soil surface immediately before transplanting. Nitrogen was applied into three equal splits at 10 days after transplanting (DAT), 30 DAT (4-5 tiller stage), and 50 DAT (7 days before panicle initiation). Other agronomic operations are presented in Table 2. Protective control measures were taken against the major insect and diseases in each of the crops as and when necessary.

Grain yield was determined by harvesting a 16 $\mathrm{m}^{2}(4 \mathrm{~m} \times 4 \mathrm{~m})$ area in the center of each plot. The grain was manually threshed and fresh grain and straw weights were determined. Grain moisture content was determined on $3 \times 100$ grain subsamples using a grain moisture meter (Model: GMK-303RS) at the time of weighing. Fresh grain yield was converted to grain yield $(\mathrm{t}$ $\mathrm{ha}^{-1}$ ) at $12 \%$ moisture content (millet) and $14 \%$ (rice).

Straw moisture content (\%) was determined on a subsample of the fresh straw which was weighed, dried at $70{ }^{\circ} \mathrm{C}$ for 3-5 days until a constant weight was achieved. Dry straw yield $(\mathrm{t}$ $\mathrm{ha}^{-1}$ ) was calculated using the following formula:

Straw y ield $($ dry,$t$ ha -1$)=\frac{\text { Oven dry wt. of sub sample }(\mathrm{g}) \times \text { Fresh straw weight }(\mathrm{kg}) \times 10000}{\text { Fresh }}$ Fresh wt. of sub sample $(\mathrm{g}) \times 16 \times 1000$ 


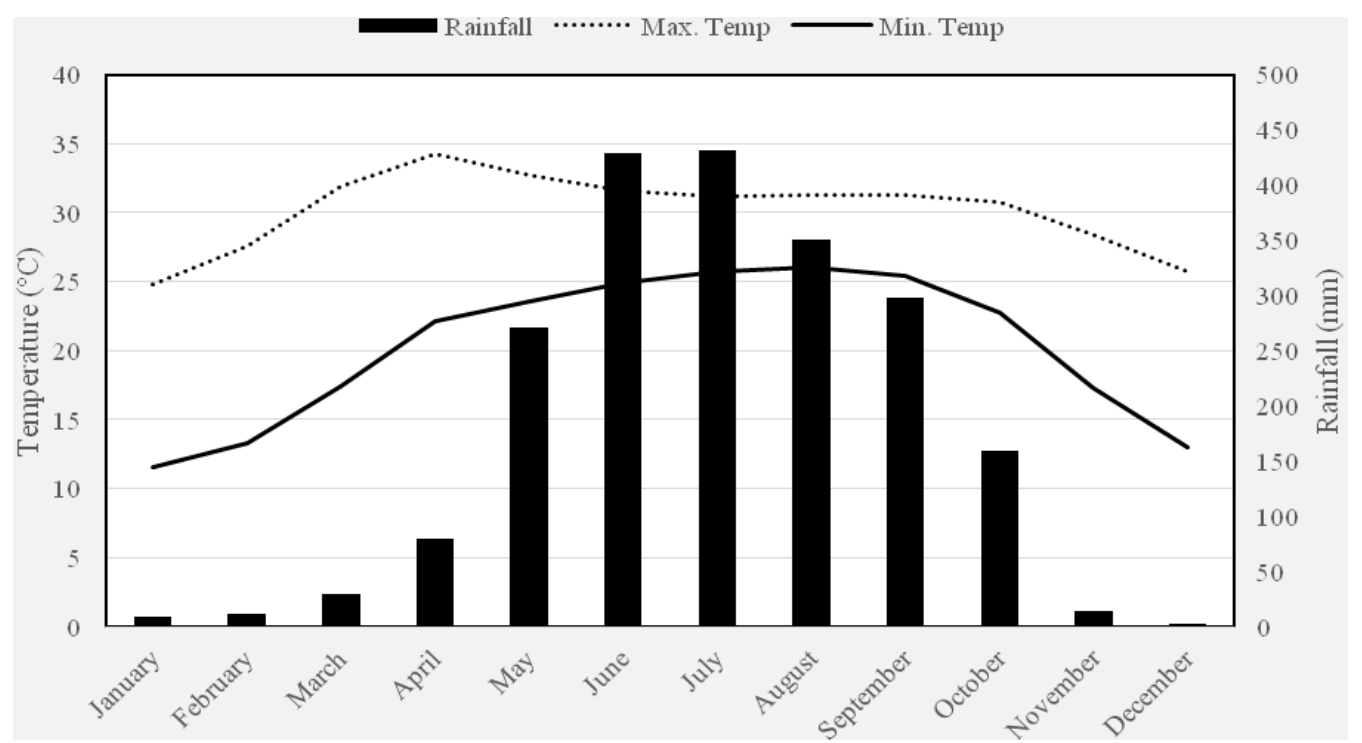

Fig. 1. Monthly rainfall $(\mathrm{mm})$ and monthly mean maximum and minimum temperature of Saghata, Gaibandha.

Table 1. Initial soil status of Chinirpotol char at Saghata, Gaibandha

\begin{tabular}{|c|c|c|c|c|c|c|c|c|}
\hline & \multirow{2}{*}{$\mathrm{pH}$} & \multirow{2}{*}{$\mathrm{OM}(\%)$} & \multirow{2}{*}{ Total N (\%) } & $\mathrm{K}$ & $\mathrm{P}$ & $S$ & $\mathrm{Zn}$ & $\mathrm{B}$ \\
\hline & & & & $\mathrm{meq} / 100 \mathrm{~g}$ & \multicolumn{4}{|c|}{$\mu \mathrm{g} / \mathrm{g}$ soil } \\
\hline Values & 7.65 & 0.83 & 0.05 & 0.14 & 9.68 & 15.2 & 0.24 & 0.25 \\
\hline Interpretation & Nutral & VL & $\mathrm{L}$ & M & $\mathrm{L}$ & M & VL & $\mathrm{L}$ \\
\hline
\end{tabular}

Table 2. Details of the crop management of existing and developed cropping patterns at Saghata, Gaibandha during 2017-18 and 2018-2019

\begin{tabular}{|c|c|c|c|c|c|c|}
\hline Pattern & \multicolumn{3}{|c|}{ Existing cropping pattern } & \multicolumn{3}{|c|}{ Improved cropping pattern } \\
\hline Crop & Millet & Fallov & T. Aman & Millet & Jute & T. Aman \\
\hline Variety & Local & - & Local (Gainja) & BARI Kaon-2 & O-9897 & Local (Gainja) \\
\hline Spacing $\left(\mathrm{cm}^{2}\right)$ & Broadcasting & - & $\begin{array}{l}\text { Discontinuous } \\
\text { transplanting }\end{array}$ & Broadcasting & Broadcasting & $\begin{array}{l}\text { Discontinuous } \\
\text { transplanting }\end{array}$ \\
\hline Unit plot size $\left(\mathrm{m}^{2}\right)$ & $10 \mathrm{~m} \times 10 \mathrm{~m}$ & - & $10 \mathrm{~m} \times 10 \mathrm{~m}$ & $10 \mathrm{~m} \times 10 \mathrm{~m}$ & $10 \mathrm{~m} \times 10 \mathrm{~m}$ & $10 \mathrm{~m} \times 10 \mathrm{~m}$ \\
\hline $\begin{array}{l}\text { Fertilizer dose } \\
(\mathrm{N}-\mathrm{P}-\mathrm{K}-\mathrm{S}-\mathrm{Zn}-\mathrm{B} \\
\left.\mathrm{kg} \mathrm{ha}^{-1}\right)\end{array}$ & $\begin{array}{l}50-15-20-5- \\
0-0\end{array}$ & - & $\begin{array}{l}30-10-20-5-0- \\
0\end{array}$ & $\begin{array}{l}2^{67-20-25-5-2-} \\
\end{array}$ & $\begin{array}{l}100-12-42- \\
20-5-2\end{array}$ & $40-10-25-5-1-1$ \\
\hline $\begin{array}{l}\text { Date of sowing/ } \\
\text { transplanting }\end{array}$ & $\begin{array}{l}15-30 \\
\text { January }\end{array}$ & & $\begin{array}{l}25 \text { Aug.-15 } \\
\text { September }\end{array}$ & 01-10 January & $\begin{array}{l}25 \text { Apr.- } 05 \\
\text { Мay }\end{array}$ & $\begin{array}{l}20 \text { Sept.-10 } \\
\text { October }\end{array}$ \\
\hline Harvesting date & 16-30 May & - & $\begin{array}{l}20-30 \\
\text { December }\end{array}$ & 20-30 April & $\begin{array}{l}23 \text { Aug.- } 02 \\
\text { September }\end{array}$ & $\begin{array}{l}20-30 \\
\text { December }\end{array}$ \\
\hline
\end{tabular}


Rice equivalent yield (REY) was calculated to compare system productivity by converting the yield of each crop into equivalent rice yield using the formula:

REY $\left(\right.$ of $\left.\operatorname{crop}_{x}\right)=Y_{x}\left(P_{x} / P_{r}\right)$

Where, $Y_{x}$ is the yield of crop ' $\mathrm{x}$ ' (tons harvested product ha $\left.{ }^{-1}\right), P_{x}$ is the price of crop, $\mathrm{x}$ and $P_{r}$ is the price of rice (Biswas et al., 2006).

The production efficiency (PE) value was calculated by dividing the total grain production $\mathrm{ha}^{-1}$ in a sequence with the total duration of crops in a sequence (Tomar and Tiwari, 1990). The total field duration of a cropping system expressed in the percentage of 365 days was taken as the land-use efficiency, LUE of the system (Tomar and Tiwari, 1990).

The cost and return analysis are included gross return, total variable cost (TVC), gross margin, and marginal benefit-cost ratio (MBCR). The gross return for each cropping pattern was calculated by multiplying the market price with crop yield while the gross margin for each cropping pattern was calculated by subtracting the TVC from gross return. The MBCR of improved cropping pattern over farmers existing patterns can be computed as the marginal value product (MVP) over the marginal value cost (MVC). The Marginal of farmer's existing pattern $(\mathrm{F})$ and improved pattern (E) for it was computed as;

Marginal Benefit Cost Ratio $($ MBCR $)=$

$\frac{\text { Gross return (E) - Gross return }(\mathrm{F})}{\text { TVC (E) - TVC (F) }}=\frac{M V P}{M V C}$

\section{Results and Discussion}

\subsection{Performance of the existing vs improved cropping pattern}

Grain yield of millet under the existing cropping pattern, were 1.25 and $1.15 \mathrm{t} \mathrm{ha}^{-1}$ during 2017-18 and 2018-19, respectively with an average of $1.20 \mathrm{t} \mathrm{ha}^{-1}$. The mean straw yield was $2.80 \mathrm{tha}^{-1}$ (Table 3). The grain yield of T. Aman rice was 2.80 and $2.60 \mathrm{tha}^{-1}$ with an average of $2.70 \mathrm{t} \mathrm{ha}$ ${ }^{1}$. Straw yields were 4.40 and $4.20 \mathrm{t} \mathrm{ha}^{-1}$ in 2017 18 and 2018-19, respectively. In the case of improved cropping pattern, the grain yield of millet was 2.61 and $2.40 \mathrm{tha}^{-1}$ with an average of $2.50 \mathrm{t} \mathrm{ha}^{-1}$. The mean straw yield was $5.70 \mathrm{t} \mathrm{ha}^{-}$ ${ }^{1}\left(5.80 \mathrm{t} \mathrm{ha}^{-1}\right.$ in 2017-18 and $5.60 \mathrm{t} \mathrm{ha}^{-1}$ in 201819). Fibre yields of jute were 2.91 and $3.10 \mathrm{tha}^{-1}$ with an average yield of $3.00 \mathrm{t} \mathrm{ha}^{-1}$. Jute stick yields were 5.80 and $6.00 \mathrm{tha}^{-1}$. Grain yields of T. Aman rice were 2.75 and $2.65 \mathrm{t} \mathrm{ha}^{-1}$ with an average of $2.70 \mathrm{t} \mathrm{ha}^{-1}$. Straw yields were 4.25 and $4.35 \mathrm{t} \mathrm{ha}^{-1}$ in two years, respectively. The grain yield of millet was double in the improved cropping pattern (Millet-Jute-T. Aman) due to the use of high yielding modern variety (BARI Kaon-2) replacing the local variety. It is mentioned that the potential yield of BARI Kaon-2 is 2.75 to $3.00 \mathrm{t} \mathrm{ha}^{-1}$ in Rabi season. Additional crop jute could be accommodated easily in the improved pattern by minimizing the field duration of Aman rice crop by seedling transplanting.

The total field duration and turnaround time were 323 and 42 days, respectively in the improved pattern whereas it was 215 and 150 days in the existing pattern. It revealed that 108 more days were used in the improved three cropbased patterns than the existing cropping pattern as well as to minimize the turnaround time. Besides, one extra crop (jute) could be easily included in the existing cropping pattern.

There was a consistent trend of higher system productivity based on rice equivalent yield (REY) of the Millet-Jute-T. Aman cropping pattern than that of the Millet-fallow- T. Aman cropping pattern (Table 3). The system productivity based on rice equivalent yield of the existing cropping pattern was very low $(4.20 \mathrm{t}$ $\left.\mathrm{ha}^{-1}\right)$, whereas the improved cropping pattern produced almost three times higher system productivity $\left(12.95 \mathrm{t} \mathrm{ha}^{-1}\right)$. The higher system productivity of the Millet-Jute-T. Aman cropping pattern than the Millet-fallow- T. Aman cropping pattern was due to the higher price received by farmers for jute and more than double crop yield in millet (replacing the local millet variety by BARI Kaon-2). Alam et al. (2017) reported that the intensification of the cropping system from double to triple cropping system increase system productivity. 
Table 3. Crop performance of improved cropping pattern, Millet-Jute-T. Aman against existing pattern Millet-Fallow-T. Aman at Saghata, Gaibandha during 2017-18 \& 2018-19

\begin{tabular}{|c|c|c|c|c|c|c|c|c|c|c|c|c|c|c|c|c|}
\hline \multirow{3}{*}{$\begin{array}{ll} & \text { Pattern } \\
\text { Crop } & \\
\text { Year } & \end{array}$} & \multicolumn{7}{|c|}{ Existing cropping pattern } & \multicolumn{9}{|c|}{ Improved cropping pattern } \\
\hline & \multicolumn{3}{|c|}{ Millet } & \multirow[t]{2}{*}{ Fallow } & \multicolumn{3}{|c|}{ T. Aman } & \multicolumn{3}{|c|}{ Millet } & \multicolumn{3}{|c|}{ Jute } & \multicolumn{3}{|c|}{ T. Aman } \\
\hline & $\frac{\infty}{\frac{1}{5}}$ & 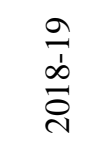 & 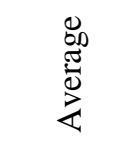 & & $\frac{\infty}{\frac{1}{5}}$ & $\begin{array}{l}\frac{a}{1} \\
\frac{\infty}{\vec{d}}\end{array}$ & 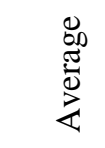 & $\frac{\infty}{\frac{1}{5}}$ & $\begin{array}{l}\frac{a}{1} \\
\frac{\infty}{\vec{d}}\end{array}$ & 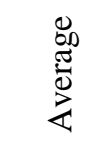 & $\frac{\infty}{\frac{\infty}{1}}$ & $\begin{array}{l}\frac{a}{1} \\
\frac{\infty}{\vec{d}}\end{array}$ & 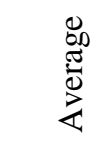 & $\frac{\frac{\infty}{1}}{\frac{\pi}{\sigma}}$ & $\begin{array}{l}\frac{a}{1} \\
\frac{\infty}{\vec{d}}\end{array}$ & 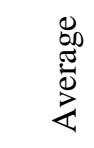 \\
\hline Variety & \multicolumn{3}{|c|}{ Local } & \multicolumn{4}{|c|}{ Local (Gainja) } & \multicolumn{3}{|c|}{ BARI Kaon-2 } & \multicolumn{3}{|c|}{ O-9897 } & \multicolumn{3}{|c|}{ Local (Gainja) } \\
\hline Field duration (day) & 125 & 123 & 124 & - & 92 & 90 & 91 & 122 & 120 & 121 & 112 & 110 & 111 & 92 & 90 & 91 \\
\hline Av. Turnaround time (day) & \multicolumn{3}{|c|}{125} & & \multicolumn{3}{|c|}{25} & \multicolumn{3}{|c|}{5} & \multicolumn{3}{|c|}{26} & \multicolumn{3}{|c|}{11} \\
\hline Grain/Fibre yield $\left(\mathrm{t} \mathrm{ha}^{-1}\right)$ & 1.25 & 1.15 & 1.20 & - & 2.80 & 2.60 & 2.70 & 2.61 & 2.40 & 2.50 & 2.91 & 3.10 & 3.00 & 2.75 & 2.65 & 2.70 \\
\hline Straw /Jute stick yield $\left(\mathrm{t} \mathrm{ha}^{-1}\right)$ & 2.90 & 2.70 & 2.80 & - & 4.40 & 4.20 & 4.30 & 5.80 & 5.60 & 5.70 & 5.80 & 6.00 & 5.90 & 4.25 & 4.35 & 4.30 \\
\hline $\begin{array}{l}\text { System productivity } \\
\left.\left(\mathrm{t} \mathrm{ha}^{-1}\right) \text { (av. of } 2 \mathrm{yrs}\right)\end{array}$ & \multicolumn{7}{|c|}{4.20} & \multicolumn{9}{|c|}{12.95} \\
\hline
\end{tabular}


Table 4. Production efficiency and land use efficiency of the cropping system

\begin{tabular}{lcccccc}
\hline \multirow{2}{*}{ Cropping systems } & \multicolumn{3}{c}{$\begin{array}{c}\text { Production efficiency } \\
\left(\mathrm{kg} \mathrm{ha}^{-1} \mathrm{day}^{-1}\right)\end{array}$} & \multicolumn{2}{c}{ Land use efficiency (\%) } \\
\cline { 2 - 7 } & $2017-18$ & $2018-19$ & Average & $2017-18$ & $2018-19$ & Average \\
\hline $\begin{array}{l}\text { Millet-Fallow-T. Aman } \\
\text { (Existing system) }\end{array}$ & 19 & 18 & 18.5 & 59 & 58 & 58.5 \\
$\begin{array}{l}\text { Millet-Jute-T. Aman } \\
\text { (Improved system) }\end{array}$ & 25 & 25 & 25 & 89 & 88 & 88.5 \\
\hline
\end{tabular}

Table 5. Economic of the two cropping patterns evaluated in the field experiment (average of two years)

\begin{tabular}{|c|c|c|c|c|c|c|}
\hline Item & $\begin{array}{l}\text { Cropping } \\
\text { pattern }\end{array}$ & 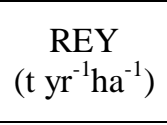 & $\begin{array}{l}\text { Gross return } \\
\left(\mathrm{Tk} \cdot \mathrm{yr}^{-1} \mathrm{ha}^{-1}\right)\end{array}$ & $\begin{array}{c}\text { Total variable } \\
\text { cost }\left(\mathrm{Tk} \cdot \mathrm{yr}^{-1} \mathrm{ha}^{-1}\right)\end{array}$ & $\begin{array}{l}\text { Gross margin } \\
\left(\mathrm{Tk} \cdot \mathrm{yr}^{-1} \mathrm{ha}^{-1}\right)\end{array}$ & $\begin{array}{l}\text { MBCR } \\
\text { (Whole } \\
\text { pattern) }\end{array}$ \\
\hline $\begin{array}{l}\text { Existing cropping } \\
\text { pattern }\end{array}$ & $\begin{array}{l}\text { Millet-Fallow- } \\
\text { T. Aman }\end{array}$ & 4.20 & 84,000 & 45,650 & 38,350 & - \\
\hline $\begin{array}{l}\text { Improved } \\
\text { cropping pattern }\end{array}$ & $\begin{array}{l}\text { Millet-Jute-T. } \\
\text { Aman }\end{array}$ & 12.95 & $2,59,000$ & $1,17,400$ & $1,41,600$ & 2.44 \\
\hline
\end{tabular}

* REY: rice equivalent yield; Price (Tk. $\left.\mathrm{kg}^{-1}\right)$ : Urea- 16, TSP- 25, MP- 15, Gypsum- 9, Zinc Sulphate130, Boric acid-140; MBCR: marginal benefit cost ratio.

\subsection{Production efficiency and land use efficiency}

Millet-Jute-T. Aman cropping system gave the highest production efficiency (PE) during both the years (Table 4$)$. The average highest PE (25 $\mathrm{kg} \mathrm{ha}{ }^{-1}$ day $^{-1}$ ) was recorded in the improved (Millet-Jute-T. Aman) cropping system, 35\% higher than the existing cropping system. The lowest PE observed in the existing system (18.5 $\mathrm{kg} \mathrm{ha}^{-1}$ day $\left.^{-1}\right)$. Millet-Jute-T. Aman expressed maximum land-use efficiency (LUE) during both the years (Table 4) with an average of $88.5 \%$ (89\% in 2017-18 and $88 \%$ in 2018-19). This system occupied land for almost similar duration, thereby achieved similar LUE. MilletFallow-T. Aman gave the lowest LUE (58 to $59 \%$ in both the year), as no summer crop was grown in this system. The results revealed that the improved cropping system increased 30\% more land use than that of existing cropping system.

\subsection{Crop and system economic performance}

The highest gross return was calculated from the improved cropping system, Millet-Jute-T. Aman (2, 59,000 Tk. ha $\left.{ }^{-1} \mathrm{yr}^{-1}\right)$, which was three times more than the existing cropping system $(84,000$ Tk. ha ${ }^{-1} \mathrm{yr}^{-1}$ ) (Table 5). The reason might be due to the double grain yield in millet of BARI Kaon-2 instead of the local millet variety and the introduction of an additional crop (jute). The total variable cost was $1,17,400 \mathrm{Tk} . \mathrm{ha}^{-1} \mathrm{yr}^{-1}$ in the improved and 45,650 Tk. ha ${ }^{-1} \mathrm{yr}^{-1}$ in the existing system. Gross margin was also more than three times higher $\left(1,41,600 \mathrm{Tk} . \mathrm{ha}^{-1} \mathrm{yr}^{-1}\right)$ in the improved cropping pattern compared to existing pattern $\left(38,350 \mathrm{Tk}\right.$. ha $\left.\mathrm{yr}^{-1}\right)$. The MBCR was calculated 2.49 in improved cropping pattern over existing cropping pattern. Alam et al. (2017) also reported that intensification from double to triple cropping system increase the profitability. 


\section{Conclusions}

This study reflected that in terms of rice equivalent yield or system productivity, production efficiency, land use efficiency and economics, the Millet-Jute-T. Aman cropping pattern/systems were superior to the Milletfallow-T. Aman system. The concerned farmers were very encouraged to learn about the developed practices, and they agreed to take this technology to increase their productivity as well as farm income. Due to growing of the three crops instead of two crops in a land in a year the cropping system productivity will be increased as well as food and economic security of the farmers will be ascertained. So, replacing Milletfallow-T. Aman by the more diverse Millet-JuteT. Aman cropping pattern should be promoted to the suitable in the char areas of Gaibandha and other similar areas.

\section{References}

Alam MJ., Humphreys E., Sarkar MAR Sudhir Yadav. 2017. Intensification and diversification increase land and water productivity and profitability of rice-based cropping systems on the High Ganges River Floodplain of Bangladesh. Field Crops Research, 209:10-26.

BBS (Bangladesh Bureau of Statistics). 2015., Statistical Yearbook of Bangladesh. Planning Division, Ministry of Planning, Government of the People's Republic of Bangladesh. 93 p.

BBS (Bangladesh Bureau of Statistics). 2018. Bangladesh Bureau of Statistics, Statistical Yearbook of Bangladesh. Planning Division, Ministry of Planning, Government of the People's Republic of Bangladesh. $140 \mathrm{p}$.

Biswas B., Ghosh DC., Dasgupta MK., Trivedi N., Timsina J., Dobermann A. 2006. Integrated assessment of cropping systems in the Eastern Indo-Gangetic plain. Field Crops Research, 99:35-47.

EGIS (Environmental and Geographical information System). 2000. Riverine
Chars in Bangladesh- environmental dynamics and management issues. Environment and GIS Support Project for Water Sector Planning (EGIS). University Press Ltd. ISBN 9840515802.

FRG (Fertilizer Recommendation Guide). 2012. Bangladesh Agricultural Research Council. BARC, Farmgate, Dhaka 1215. $19 \mathrm{p}$.

Islam MA., Mahmud AA., Molla MSH., Ali MA. 2017. Cultivation of minor cerealsMillet and Proso millet in Char land areas (Bangla). On-Farm Research Division, Bangladesh Agricultural Research Institute (BARI), Joydebpur, Gazipur1701.

Karim M A., Haque MM., Hamid A. 2014. Concern, Opportunity and Strategic Research in Crop Sector under Climate Change Context in Bangladesh. In: Rising Atmospheric CO2 and Crop Response. A compendium of published works at BSMRAU, Bangabandhu SMR Agricultural University (Gazipur). 1-64 pp.

Karim MA., Quayyum MA., Samsuzzaman S., Higuchi H., Nawata E. 2017. Challenges and Opportunities in Crop Production in Different Types of Char Lands of Bangladesh: Diversity in Crops and Cropping. Tropical Agriculture and Development, 61(2):77-93.

Rahman S., Kajal MMH., Begum IA., Alam MJ. 2017. Exploring the future potential of jute in Bangladesh. Agriculture, 7: 1-16. doi:10.3390 /agriculture7120096

Sattar SA., Islam MN. 2010. Char lands of Bangladesh: their extent, management and future research needs. Papers presented in a workshop on Soil Fertility, Fertilizer Management and Future Strategy held at Bangladesh Agricultural Research Council, Farmgate, Dhaka during 18-19 January, 2010. 1-9 pp.

Tomar SS., Tiwari AS. 1990. Production potential and economics of different cropping sequences. Indian Journal of Agronomy, 35(1, 2): 30-35. 